\section{IJIKMMENA}

2,2

\section{5}

\title{
CORRUPTION AND ECONOMIC DEVELOPMENT: A PUZZLING RELATIONSHIP
}

\author{
Beverlee B.Anderson' \\ California State University, USA
}

\begin{abstract}
Purpose: The purpose of this paper is to explore the relationships that are thought to exist between the corruption within a country and selected components that contribute to a country's sustainable economic development across regions of the world.

Design/methodology/approach: Using data from the World Bank on various aspects of development and data from Transparency International on perceptions of types and levels of corruption, a series of statistical models were developed to examine relationships among corruption in its various forms and dimensions of economic development.

Research limitations: The research is limited by the availability of data from the two sources over the time-frame examined.

Findings: The findings are mixed, showing that some types of corruption have greater negative impact on specific aspects of economic development; however, it appears that the effect may be moderated by other country factors. Originality/value: The study uses secondary data, which are judged to be the most valid and reliable, and examines a variety of relationships.

Practical implications: The impact of corruption on economic development may be moderated by cultural and "other" factors.
\end{abstract}

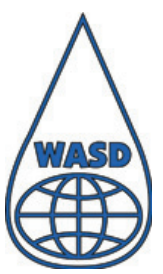

International Journal of Innovation and Knowledge Management in Middle East \& North Africa Vol. 2 No. 2, 2013

Copyright (C) 2013 WASD

Keywords: Corruption levels and Economic Development, FDI, GDP growth and Capital Formation

Paper type: Research paper

${ }^{1}$ Professor Beverlee B. Anderson, College of Business Administration, California State University San Marcos, San Marcos, CA 92096-0001 USA, Email: banderso@csusm.edu 


\section{INTRODUCTION AND BACKGROUND}

Sustained economic growth is the goal of most countries and regions. Economic development provides jobs and resources for citizens and governments. Through the years, research studies have explored a variety of factors that were thought to be associated with economic development. Corruption's role in economic growth, however, was not considered in the historical development of economic theories because corruption was "not perceived as an economic problem" according to Volejníková (2009). It was not until later that corruption was considered relevant to economic growth. Interest in how corruption impacts economic development has increased dramatically since the 1990s. Haggard and Tiede (2011) trace the surge of interest from a 1995 article by Mauro reporting that lower investment and growth was associated with higher corruption levels as measured by surveys of investors. Since then, a plethora of articles have explored various aspects of corruption. Many of these articles examining different aspects of corruption and using different methods found that some aspects of corruption adversely affect economic growth. These articles led to the "status of received wisdom" (Haggard and Tiede, p. 675) that corruption adversely affects economic growth. For example, Wei (1999) reviewed overwhelming statistical evidence that "countries with high levels of corruption experience poor economic performance". He concluded that corruption hinders economic development by reducing domestic investment, discouraging foreign direct investment, encouraging overspending in government, and distorting the composition of government spending (away from education, health and infrastructure maintenance toward less efficient but more manipulatable public projects, p. 2). Transparency International's Global Corruption Barometer (2010) reported that globally, political parties are judged to be most affected by corruption, as almost eighty per cent of respondents think political parties are either corrupt or extremely corrupt. Other groups seen as being affected by corruption in rank order are: public officials, parliament/legislature, police, businesses/private sector, religious bodies, judiciary, media, education system, NGOs and military.

Another perspective on corruption is presented by Volejníková (2009), who recognized that corruption is a form of economic behaviour that was, is, and most likely will continue to be practiced by economic entities. She suggested that corruption will have significant impact on the "quality of the economy of individual as well as economy of government (p. 15)".

\section{Corruption} and economic development: A puzzling relationship 
IJIKMMENA 2,2
There are, however, many examples of high economic growth in countries perceived as having relatively high levels of corruption. For example, India has achieved relatively high rates of economic growth while ranking as one of the more corrupt countries on a perception of corruption index (Transparency International 2010).

Corruption can take various forms, but a widely accepted definition of corruption is the one adopted by the United Nations:" The abuse of public office for private gains" (United Nations' Convention against Corruption, 2003). Transparency International's Global Corruption Barometer (2010) reported that petty bribery is the most common form of corruption and police are the institution most often reported as recipient of bribes. The police are closely followed by registry and permit services. Others who are also perceived as participating in petty bribery are the judiciary, customs, utilities, medical services, education system, land services and tax authorities.

Harstad and Svensson (2011) examined the reaction of firms when faced with regulatory constraints. Such constraints frequently result in holdup problems, which firms must overcome. In more developed countries, firms may try to lobby the regulators to solve the holdup problems. In contrast, in less developed countries, these holdups are likely to be more easily alleviated by paying bribes to government officials. If the holdup problems are very severe, firms will not invest enough to make lobbying an economically feasible alternative.

\section{AID, CORRUPTION AND ECONOMIC DEVELOPMENT}

After major natural disasters or devastations, aid organizations may use the reconstructive process to promote "a wider agenda of economic and political reform" with the goal of developing a stronger and more stable climate for investors in reconstructive aid. These efforts may be thwarted by mismanagement and corruption, which was found to jeopardize the "flow of reconstructive aid to Nicaragua and even its qualification for HIPC debt relief" as it attempted to rebuilt after Hurricane Mitch in 1998 (Oxford Analytica Daily Brief, 2000).

Chheang's (2009) study using panel data from sixty-seven countries found that aid had no positive effect on economic growth. However, he did find aid to be positively related to reducing corruption, which 
may have resulted from an improvement in the quality of governance of the countries.

In a study of forty developing countries, Choi and Woo (2011) found that economic growth did not improve distributive justice in corrupt countries, and generally left the level of inequality intact. In contrast, economic liberalization had little impact on faster growth, poverty levels or reduction in inequality.

Corruption and economic development: A puzzling relationship

\section{Cultural factors and economic growth}

Around fifty years ago the relationship between culture and economic growth was a topic of study, but it faded in importance during the 70s and 80s (Yeh and Lawrence 1995). It was not until the rapid growth of East Asian countries that there was a resurgence in interest in this topic. One of the most noted individuals to study this relationship was Geert Hofstede and his associates (Hofstede 1980a; Hofstede and Bond 1988; Franke, Hofstede and Bond, 1991; Hofstede, 1991). Hofstede's Five Dimensions of Culture are widely accepted as capturing salient aspects of culture. While there have been several studies on culture and factors of economic development, few studies have examined the relationship of culture and corruption within a country. The purpose of this study is to explore the relationships among corruption, economic development and culture.

\section{METHODOLOGY}

The research approach is a descriptive research design using secondary data. The purpose of the research was to more clearly understand the relationships between corruption indicators and various factors of economic growth. In the course of the study, the role of culture also appeared to be a moderating or influencing factor. The study's research questions are:

1. Is there a relationship between corruption levels and GDP growth?

2. Are there relationships among factors of economic development: Capital Formation, Direct Foreign Investment and Aid Assistance, and GDP growth?

3. Are there relationships between corruption and factors of economic development? 
IJIKMMENA

2,2

4. Is there a relationship between cultural values and economic development?

5. Is there a relationship between cultural values and level of corruption?

To answer these research questions, the following sources of secondary data were utilized:

Corruption data: The core data used in this study are from Transparency International, which collects data on the general public's views on and experiences of corruption. From the survey data published between January 2009 and September 2010, the organization creates a corruption perception index (CPI) for the 178 countries surveyed. The index ranges from 0 (highly corrupt) to 10 (very clean). In 2010, the least corrupt countries were Denmark, New Zealand and Singapore - all tied with scores of 9.3. The most corrupt country on the list was Somalia, with a score of 1.1 .

Economic data: Economic data used in the study are from the World Bank's Data Bank (http://data.worldbank.org) The data analyzed include: 1) Gross Domestic Product Growth for 2010, which is "calculated as the annual percentage growth rate of GDP at market prices based on constant local currency. It is the sum of gross value added by all resident producers in the economy" (156 countries); 2) Capital Formation data, which includes "outlays on additions to the fixed assets of the economy plus net changes in the level of inventories" (134 countries); 3) Direct Foreign Investment for 2005 (164 countries) and for 2010 (154 countries), which includes "new investment inflows less disinvestment by foreign investors divided by GDP”.4) Aid Assistance for 2009, which consists of "disbursements of loans made on concessional terms and grants by official agencies of members of the Development Assistance Committee by multilateral institutions and by non-DAC countries to promote economic development" (124 countries).

\section{CULTURAL VALUES DATA}

In addition to corruption and economic data, information on country culture was also included in the study. Cultural values and characteristics data are based on Hofstede's five dimensions of national cultures: individualism/collectivism; power distance; masculinity/femininity; uncertainty avoidance; and long/short term orientation. Of the 
178 countries identified with a CPI, the Hofstede Cultural dimensions scores were available on 4 dimensions for 91 countries, while scores for long/short term orientation were available for only 43 countries. (http://geert-hofstede.com/countries.html

\section{ANALYSIS}

A PASW data file was created based on the data collected. Preliminary analyses were run to determine the existence of any statistically significant relationships between scores on the CPI and Economic indicators and among the economic indicators. The results of these analyses are shown in Table 1.

Next, a step-wise regression analysis was run with GDP Growth as the dependent variable and corruption index and other economic factors as independent variables. Only one variable entered the regression formulation: Capital Formation. With an R-Square of .542, it appears that Capital Formation explains over half of the variance in GDP growth. The other economic factors did not increase the explanatory value of the model.

This led to an analysis of factors related to Capital Formation. The only economic variable that entered the regression formula was DFI 2010. While significant, the R-Square was .167, which shows that DFI explained only a relatively small portion of the variance in the Capital Formation of a country.

\begin{tabular}{lclllll} 
& CPI & $\begin{array}{l}\text { GDP } \\
\text { Growth }\end{array}$ & $\begin{array}{l}\text { Capital } \\
\text { Formation }\end{array}$ & $\begin{array}{l}\text { DFI } \\
2005\end{array}$ & $\begin{array}{l}\text { DFI } \\
2010\end{array}$ & $\begin{array}{l}\text { Aid } \\
\text { Assistance }\end{array}$ \\
CPI & 1.00 & -.060 & $-.306^{* *}$ & $.187^{*}$ & $.171^{*}$ & $-.257^{* *}$ \\
GDP Growth & -.060 & 1.00 & .086 & -.026 & .009 & .169 \\
Capital & $-.306^{* *}$ & .145 & 1.00 & -.038 & -.004 & -.021 \\
Formation & & & & & & \\
DFI 2005 & $.187^{*}$ & -.026 & -.038 & 1.00 & $.932 * *$ & -.056 \\
DFI 2010 & $.171^{*}$ & .009 & -.004 & $.932 * *$ & 1.00 & -.140 \\
Aid Assistance & $-.257^{* *}$ & .169 & -.021 & -.026 & .009 & 1.00 \\
\hline
\end{tabular}

*Correlation is significant at the 0.05 level (2-tailed).

** Correlation is significant at the 0.01 level (2-tailed).

Table I

Parameters with distance for each area 
IJIKMMENA

2,2

191

Next, cultural factors were analyzed. The associations between Hofstede's Five National cultural dimensions, corruption and economic factors are shown in Table 2.

\section{FINDINGS AND DISCUSSION}

\section{Research question \#1}

1. Is there a relationship between corruption levels and GDP growth?

Based on the correlations reported in Table 1, there does not appear to be a statistically significant relationship between corruption as measured by CPI and GDP Growth. While the weak correlation is negative, it shows that GDP Growth tends to be somewhat associated with less corrupt countries; however the finding is not statistically significant.

\section{Research question \#2}

2. Are there relationships among factors of economic development: capital formation, Direct Foreign Investment and Aid Assistance, and GDP growth?

The findings show little relationship among the economic factors of Capital Formation, and Direct Foreign Investment to GDP Growth. DFI in 2005 is related to DFI in 2010, but otherwise, the economic factors do not appear to be related. The only factor that appears to be related to other economic aspects is Aid Assistance.

Using GDP Growth in 2010 figures, which were available for 156 countries, a correlation analysis produced a statistically significant $(p=0.05)$ negative correlation. This analysis supports Chheang's results

Table 2.

Correlations betweencultural dimensionscorruption and economic factors

\begin{tabular}{lllllll} 
& CPI & $\begin{array}{l}\text { GDP } \\
\text { Growth }\end{array}$ & $\begin{array}{l}\text { Capital } \\
\text { Formation }\end{array}$ & $\begin{array}{l}\text { DFI } \\
2005\end{array}$ & $\begin{array}{l}\text { DFI } \\
2010\end{array}$ & $\begin{array}{l}\text { Aid } \\
\text { Assistance }\end{array}$ \\
Power Distance & $-.663 * *$ & .119 & $.391 * *$ & -.135 & -.103 & .043 \\
Uncertainty & -.155 & $-.233 *$ & -.205 & .023 & -.023 & -.230 \\
Individualistic & $.670^{* *}$ & -.134 & $-.367 * *$ & .097 & .073 & -.041 \\
Masculine/Fem & -.189 & .080 & .045 & -.010 & -.038 & .143 \\
Long/Short term & .098 & .184 & $.543 * *$ & .103 & .192 & -.297 \\
\hline
\end{tabular}

*Correlation is significant at the 0.05 level (2-tailed).

** Correlation is significant at the 0.01 level (2-tailed). 
in that there appears to be a negative relationship between aid and economic growth.

\section{Research question \#3}

3. Are there relationships between corruption and factors of economic development?

Corruption and economic development: A puzzling relationship

When examining the corruption index of 173 countries, 124 countries received various levels of aid (Net official development assistance and official aid received) in 2009. There was a statistically significant negative correlation between the corruption index of a country and Aid Assistance. It was significant at the 0.01 level using a 2-tailed test. A step-wise regression analysis was then performed with Aid Assistance as the independent variable and corruption as the dependent variable. The findings again show statistical significance, with Aid Assistance having a negative coefficient. It therefore appears that aid is negatively associated with corruption. Whether or not aid contributed to a nation being less corrupt or whether it means that more aid was given to the least corrupt nations is not discernible with the available data. But logic would suggest that aid is more likely to be given to less corrupt countries. Perceived corruption will likely negatively influence the giving of aid, as happened in Nicaragua after Hurricane Mitch.

\section{Research question \#4}

4. Is there a relationship between cultural values and economic development?

Hofstede and his co-authors (1980, 1988, 1991) presented evidence that they said showed a link between national culture and economic growth. This was, however, contested by Yeh and Lawrence (1995), who contended that two of Hofstede's dimensions, Power Distance and Confucian dynamism (long/short term view), were not independent variables. However, the values data analyzed in this study for 81 countries did not find the two dimensions to be correlated. Therefore, all five dimensions were treated as independent. Using analysis of variance with GDP Growth as the dependent variable, and the dimensions of culture as independent, three dimensions of culture were found to be related to GDP Growth: Individualism, Uncertainty and Power Distance.

Individualism is defined by Hofstede (2012) as a "preference for loosely knit social framework in which individuals are expected to take care of themselves and their immediate families". Another way to look at this dimension is one of self-reliance rather than relying on others 
IJIKMMENA

2,2

for one's needs. In cultures where individualism is prominent, it appears that people may be more motivated and work hard to provide for their families, which can lead to economic growth.

Uncertainty avoidance relates to the degree to which people in a culture are un-comfortable with uncertainty or ambiguity (Hofstede 2012). Cultures that rate low on uncertainty avoidance can tolerate a relatively high level of ambiguity. The association of the desire for clarity and transparency with economic growth supports the notion that communication and transparency are important in developing a growth economy.

Power distance expresses "the degree to which the less powerful members of society accept and expect the power is distributed unequally" (Hofstede 2012). Just as Porter (2008) says, when competitors in an industry are roughly equal in size and power (low power distance), practices desirable for the industry as a whole go unenforced. Balanced power frequently leads to instability, as there is jockeying among participants for position. When a culture accepts that some have more power than others, it is easier to enforce policies that may benefit the entire economy, thus economic growth may be easier to obtain.

When examining another aspect of economic development, Capital Formation, with the five cultural dimensions, three were found to be related. Power Distance and Confucian dynamism (Long/Short term) were found to be positively related to Capital Formation; however another dimension of culture was also significant. Individualism was negatively related to Capital Formation, suggesting that the less individualistic a culture, the greater the Capital Formation. This may be due to the collectivism orientation, where funds are aggregated for economic endeavors.

None of the five dimensions of culture were found to be related to Direct Foreign Investment or Aid Assistance to a country. Thus, it appears that there is some relationship between culture and economic factors, but the relationship is not particularly clear or overwhelming.

\section{Research question \#5}

5. Is there a relationship between cultural values and level of corruption?

To examine the relationship between cultural values and level of corruption, a step-wise linear regression was used with the five dimensions of cultural values as independent variables and corruption level as the dependent variable. Of Hofstede's five dimensions of culture, only one dimension entered the regression model, and that was Power Distance. 
The R-Square for this analysis was .428, and the $F=19.49$ is significant at the .000 level.

\section{CONCLUSIONS}

The relationship of culture, corruption and economic development appears to be linked; however, the exact relationships are puzzling. Corruption does not appear to be directly correlated with Hofstede's cultural dimensions, but at the same time the linkages between corruption and economic development and culture exist. The unravelling of these puzzling relationships provides many opportunities for research projects in the future. Uncovering how these factors work together and/or against each other has the potential to help countries develop sustainable economic growth.

\section{REFERENCES}

Business Monitor (2010), "Global Political Outlook -What to Expect in 2011", downloaded on March 29, 2011 from http://www. businesmonitor.com/cgibin/request.pl?view=print

Chheang, V. (2009), "The Effect of Foreign Aid on economic Growth and Corruption in 67 Developing Countries", unpublished Master's thesis submitted to Graduate School of Arts and Science of Georgetown University.

Choi, E. and Woo, J. (2011), "Liberal Reform, Political Corruption, and Socio-economic Impacts in Asia and Eastern Europe", International Journal Of Comparative Sociology, Vol. 52 No. 3, pp. 181-196.

Europa (2007), "A Comprehensive EU anti-corruption Policy", downloaded on March 4, 2012 from http://europa.eu/legislation_ summaries/fight_against_fraud/fight_

Franke, R. H., Hofstede, G., Bond, M. H. (1991), "Cultural Roots of Economic Performance: A Research Note”, Strateic Management Journal, Vol. 12, Special Issue, pp. 165-173.

Haggard, S. and Tiede, L. (2011), "The Rule of Law and Economic Growth: Where are We?", World Development, Vol. 39, No. 5, pp. 673-685.

Harstad, B. and Svensson, J. (2011), "Bribes, Lobbying, and Development", American Political Science Review, Vol. 105, No.1 pp. 46-63.
Corruption and economic development: A puzzling relationship 
IJIKMMENA

2,2
Hofstede, G. (1980a), Culture's Consequence: International Differences in Work-Related Values, BeveryHills, CA, Sage Publications.

Hofstede, G. (1980b), "Motivation, leadership, and organization: Do American theories Apply Abroad?", Organizational Dynamics, Vol. 9, No.1, pp. 42-631.

Hofstede, G. (1991), Culture and Organisations, New York, McGraw-Hill.

Hofstede, G. and Bond, M.H. (1988), "The Confucius Connection: From Cultural Roots to Economic Growth", Organizational Dynamics, Vol. 16. No. 4, pp. 5-21. (2011) http://geert-hofstede.com/countries. html (2012) http://geert-hofstede.com/dimensions.html

Mauro, P. (1995), "Corruption and Growth", Quarterly Journal of Economics, Vol. 110, No. 3, pp. 681-712.

Organization of American States (2007), "Agreement Signed at OAS to Strengthen Fight against Corruption”, Press Release, April 13, 2007, downloaded on March 4, 2011 from http://www.oas.org/en/media_ center/press_release.asp?sCodigo =

Oxford Analytica Daily Brief Service (2000), "Corruption Hampers Central America Aid", downloaded on March 26 from http:// ezproxy.csusm.edu/login? url=http://search.proquest.com/docview/1 92433700? accountid=10363

Porter, M. (2008), "The Five Competitive Forces that Shape Strategy", Harvard Business Review, January 2008, pp. 2-17.

Transparency International (2011), Global Corruption Barometer 2010, downloaded on January 15, 2012 from http:// www.transparency.org. (2011) Corruption Perceptions Index 2010, downloaded on January 17, 2012 from http://www.transparency.org (2008), Press release, "TI Report: Emerging Economic Giants Show high levels of corporate bribery overseas", downloaded on March 21,2011 from: http://www.transparency. org/new_room/latest_news/press_release (2012) Corruption Perception Index 201, downloaded on March 23, 2012 from http://cpi.transparency. org/cpi2011/results/\#CountryResults

United Nations, (2003), "United Nations Convention against Corruption", downloaded on March12, 2011 from http://www.unodc. org/unodc/en/treaties/CAC/index.html

Volejníková, J. (2009), "Reflection of Corruption in the Development of Economic Theories", E +M Ekonomie a Management, Vol. 2, pp. 15-34. 
Download on March 6, 2012 from http://search.proquest.co/docview/ 195457882 ?accountid=10363

Wei, Shang-Jin, (1999), "Corruption in Economic Development: Beneficial Grease, Minor Annoyance, or Major Obstacle?" World Bank Policy Research

Working Paper No. 2048. SSRN Working Paper Series (2004), downloaded onMarch26, 2012 from http://ezproxy.cussm.edu/login? url=http:// search.proquest.com/docview/189913409?accountid=10363

World Bank National Accounts data, and OECD National Accounts data files (2011), downloaded on January 16, 2012 from http://data. worldbank.org/indicator/NY.GDP.MKTP.KD.ZG

World Development Indicators, "Net Official Development Assistance and Official Aid Received", downloaded on January 3, 2012 from http://www.oecd.org/dac/stats/idsonline "Gross Capital Formation", World Bank National accounts data and OECD National Accounts data files, downloaded on January 3, 2012 from http://data.worldbank. org/indicator/NE.GDI.TOTL.ZS

Yeh, R. and Lawrence, J. (1995), "Individualism and Confucian Dynamism: A Note on Hofstede's Cultural Root to Economic Growth", Journal of International Business Studies, Third Quarter, pp. 655-669.

\section{ABOUT THE AUTHOR}

Beverlee B. Anderson received her Ph.D. in Marketing from The Ohio State University. She currently serves as Professor of Business and Marketing at California State University San Marcos. She has held a variety of teaching and administrative positions at universities in the United States. She is past President of the Marketing Educators Association and has taught in graduate programmes in Mexico and India.
Corruption and economic development: A puzzling relationship 